\title{
ENTRAR, FICAR OU SAIR DO LABIRINTO? O CONSTITUCIONALISMO E A SIMULTANEIDADE - SOCIAL, AMBIENTAL E GLOBAL - DOS ACONTECIMENTOS
}

\author{
Francisco Quintanilha Veras Neto ${ }^{1}$ \\ Bruno Cozza Saraiva ${ }^{2}$ \\ Marcia Regina da Silva Quintanilha Veras ${ }^{3}$
}

\begin{abstract}
"Holz [madeira, lenha] é um nome antigo para Wald [floresta]. Na floresta [holz] há caminhos que, o mais das vezes sinuosos, terminam perdendo-se, subitamente, no não-trilhado. Chamam-se caminhos de floresta [Holzwege]. Cada um segue separado, mas na mesma floresta [Wald]. Parece, muitas vezes, que um é igual ao outro. Porém, apenas parece ser assim" (HEIDEGGER, 2014, p.3).
\end{abstract}

\section{Resumo}

O presente trabalho tem como objetivo discorrer acerca do Mito - metáfora - do Labirinto assim como também do constitucionalismo como responsabilidade civilizacional e, ao mesmo tempo, como resgate - contemporâneo - do mitológico Fio de Ariadne. Também, se discutirá, neste texto, sobre a ciência, a tecnologia e o mercado como representações do projeto antropológico moderno que, substancialmente, instituiu e institui - progressivamente - um cenário labiríntico de destruição ambiental.

Palavras-chave: Mito; Labirinto; Crise Ecológica; Constitucionalismo; Globalização.

\section{CONSIDERAÇÕES INICIAIS}

A figura do labirinto nem sempre foi percebida da forma que se lhe percebe na contemporaneidade. Sua

\footnotetext{
${ }^{1}$ Pós-Doutor em Direito pela Universidade Federal de Santa Catarina. Professor Associado II e Professor do Programa de Pósgraduação em Direito e Justiça Social da Universidade Federal do Rio Grande (FADIR).E-mail: quintaveras@gmail.com ${ }^{2}$ Doutorando em Direito Público na Universidade do Vale do Rio dos Sinos (UNISINOS). Bolsista CAPES. Integrante do Grupo de Pesquisa Estado e Constituição (CNPq) e do Grupo Transdisciplinar de Pesquisa Jurídica para a Sustentabilidade/GTJUS (CNPq).E-mail: brunocozza19@hotmail.com

${ }^{3}$ Graduanda em Letras Licenciatura Português pela Universidade Federal do Rio Grande (FURG). Graduada em Pedagogia Pela Universidade Federal de Santa Catarina (UFSC). Especialista em Psicopedagogia pela Universidade do Sul de Santa Catarina (UNISUL).E-mail: marciaveras@gmail.com
} 
origem longínqua liga-se às experiências míticas e às ritualísticas que se inserem no universo do sagrado. A sua imagem, por assim dizer, evoca o Mito do Herói, cuja praxe imposta, dentro dos caminhos labirínticos do território do Minotauro, impõe uma escolha entre a pluralidade de caminhos para a chegada e a multiplicidade de caminhos para a saída da armadilha criada por Dédalo.

Neste espaço, o Herói se encontra diante de diversos caminhos que colocam o dilema existencial da escolha. A sua saída, possibilitada pela ajuda do destino, é posta pelo Fio de Ariadne que tece um único caminho como dissipador das incertezas. O tempo no labirinto é um tempo mítico, linear, cíclico, do eterno retorno, um tempo paralelo ao tempo do espaço real.

Dessa forma, a metáfora do labirinto, em um cenário pós-nacional ${ }^{4} \mathrm{e}$ de simbolismo constitucional, se faz representar por um horizonte a-histórico que cria rupturas, fissuras intransponíveis no paradigma jurídico da certeza (modernidade). Só há uma saída? Só há um Direito? O Herói representado pelo ideal mitologizado (tradição jurídica ocidental) se constitui no Fio de Ariadne para o "Ser aî" e se posiciona, substancialmente e contemporaneamente, entre conflitos, lutas, desigualdades e catastrofização ambiental.

Em consequência disso, no vácuo das utopias do progresso, a distopia ocasionada pelo labirinto fragiliza o Direito do Estado Social e elimina a possibilidade-construção de um novo paradigma ecológico como insurgência - Fio de Ariadne - desta e entre esta nova metanarrativa economicista. Parece, assim, que, ao se compreender o mercado como personificação do Herói, o Direito não deve representar um obstáculo e, o social e o ambiental, de forma alguma deverão se transformar no Minotauro, cuja função primordial é a de destruir-regular o "Herói".

Portanto, em um mundo-labirinto pós-nacional, determinado pela erosão do paradigma jurídico moderno - desjuridicização ${ }^{5}$ - bem como também pela "relatividade espacial, temporal e conceptual", no

\footnotetext{
${ }^{4}$ Em 1992, o livro de Paolo Prodi, Il sacramento del potere, chamou fortemente a atenção para a importância decisiva do juramento na história política do Ocidente. Situado entre como articulação entre religião e política, o juramento não só testemunha a "dupla pertinência" (Prodi, p. 522) que define, segundo o autor, a especificidade e a vitalidade da cultura ocidental cristã; ele, de fato, foi também - tal é o diagnóstico de que parte o livro (ibid., p. 11) - a "base do pacto político na história do Ocidente", que, enquanto tal, é possível encontrar exercendo um papel importante toda vez que este pacto entra em crise ou volta a ser reatado de maneiras diferentes, do início do cristianismo até a luta pelas investiduras, desde a "sociedade jurada" da Idade Média tardia até a formação do Estado moderno. Coerente com essa sua função central, o declínio irreversível do juramento em nosso tempo tem tudo a ver, segundo Prodi, com uma "crise que investe o próprio ser do homem como animal político" (ibid). Se atualmente somos "as primeiras gerações que, não obstante a presença de algumas formas e liturgias do passado (...), vivem a própria vida coletiva sem o juramento como vínculo solene e total, sacralmente ancorado, a um corpo político" (ibid.), isso significa, então, que nos encontramos, sem termos consciência disso, no limiar de "novas formas de associação política", cuja realidade e cujo sentido ainda nos resta degustar (AGAMBEN, 2011, p. 9).

5 [...] A crise constitucional se apresenta, na linha primordial para a presente discussão, desde fora, como processo de desconstitucionalização promovido pelo dito neoliberalismo, além de se ver constrangida, muitas vezes, pelo descompasso entre as promessas que contempla, a vontade política e as condições econômicas para a sua realização. Assim, o que temos vislumbrado na prática é o reforço desta postura, quando as Constituições e o próprio constitucionalismo moderno são revisitados, sobretudo, quando vista desde o perfil mercadológico característico do capitalismo financeiro globalizado, na medida em que "com o prevalecimento da lógica mercantil e a já mencionada contaminação de todas as esferas da vida social pelos imperativos categóricos
} 
presente estudo, se buscará discorrer acerca do Fio de Ariadne como condição de possibilidade destinada à construção-edificação de um constitucionalismo mundial comprometido com a mitigação ou reversão do colapso ecológico-civilizatório.

Para isso, a metodologia empregada no texto ou, melhor, o método de abordagem utilizado será o hermenêutico fenomenológico ${ }^{7}$, pois, este método de compreensão se mostrará, por sua vez, suficientemente fértil e adequado para a discussão da temática objeto desta investigação.

\section{MITO: DE COMO TUDO COMEÇOU}

A sociedade contemporânea imersa na tecnologia assim como também na tecnocracia reintegra, por sua vez, o Mito como forma subjacente de dar sentido à trajetória existencial humana. Neste contexto e, ao longo do século XX, estudiosos de diferentes áreas do conhecimento, isto é, da psicanálise, da antropologia e da hermenêutica, conjuntamente à estudiosos de religião, buscaram, no Mito e em outros elementos simbólicos, a função primeira de proporcionar ao homem um equilíbrio biopsicossocial.

Com isso, a compreensão do Mito, a partir do senso comum e, fundamentalmente, como uma narrativa fictícia e imaginária, ganhou, progressivamente, novas dimensões e significações nos estudos de Gaston Bachelard, Gilbert Durand, Campbell e Mircea Eliade. Isto porque, estes estudiosos, traduziram, por sua vez, as diferentes perspectivas hermenêuticas instauradoras do simbolismo, e que, em consequência disso, integraram um diálogo de essencial importância entre ciência e mito, de modo que, a Filosofia Clássica, de maneira cronológica, racionalizou a narrativa mitológica e a inseriu no plano da fantasia e da imaginação.

Além disso, ao longo dos séculos, com o aumento do fosso entre o imaginário e o pensamento pragmático e racional, a mais clara depreciação do símbolo surge e prepondera, substancialmente, a partir do pensamento de René Descartes (Sec. XVII) e a "imaginação, como, aliás, a sensação, é rejeitada por todos os cartesianos como a senhora dos erros" (DURAND, 1988, p.25). No entanto, em contrapartida, o empirismo do

do sistema econômico, a concepção de uma ordem constitucional subordinada a um padrão político e moral se esvanece", perdendo-se, com isso, o que Dalmo de Abreu Dallari chamou de padrão objetivo do justo, muito embora tenha-se que relativizar esta objetividade, tratando-a, como dito acima, como um referencial ético-jurídico que busca garantir conteúdos mínimos de convívio social, como também estabelecendo limites positivos para a consolidação de suas promessas formuladas como declarações de vontades políticas (BOLZAN DE MORAIS, 2011, p. 53-54).

${ }^{6}$ Uma paisagem revolucionada em que as regras de direito parecem surgir de todo lado, a todo momento e em todos os sentidos: relatividade espacial, temporal e conceptual que embaralha todos os pontos de referência habituais, deixando ver um espaço normativo "desestatizado", um tempo "desestabilizado" e uma ordem "deslegalizada" (DELMAS-MARTY, 2004, p. 46).

${ }^{7} \mathrm{O}$ termo fenomenologia tem, portanto, um sentido diferente das designaçōes como teologia, etc. Estas evocam os objetos de suas respectivas ciências, em seu conteúdo quididativo. O termo "fenomenologia" não evoca o objeto de duas pesquisas nem caracteriza o seu conteúdo quididativo. A palavra se refere exclusivamente ao modo como se demonstra e se trata o que nesta ciência deve ser tratado. Ciência "dos" fenômenos significa: apreender os objetos de tal maneria que se deve tratar de tudo que está em discussão, numa demonstração e procedimento diretos. $\mathrm{O}$ mesmo sentido possui a expressão, no fundo tautológica, de "fenomenologia 
século XVIII, enquanto postura filosófica, não rompeu com a herança iconoclasta, pois, para esta corrente, todo o conhecimento deriva da experiência direta, ou seja, da observação. Por outras palavras, durante estes dois séculos (XVII e XVIII), a imaginação perdeu, cada vez mais, espaço para as explicações racionalistas e cientificistas do mundo. E, em consequência disso, no que se refere à legitimidade e à manutenção científica e social da imaginação, da fantasia e do mito, se pode dizer que, na contemporaneidade, estas se encontram preservadas unicamente no campo das artes.

Ademais, em decorrência disso, no século XIX, a racionalidade cientificista, isto é, o modo pelo qual a ciência explica a natureza, se disseminou e, da mesma forma, passou a compreender e a explicar também os fenômenos sociais e, com isso, progressivamente, lançou as bases do e para o positivismo. De fato, esta concepção que, por sua vez, preponderou por todo o século XIX e sustentou os saberes acadêmicos, possibilitou, sobretudo, a criação das bases ideológicas para a Revolução Industrial, se tornando, assim, uma verdade segura e objetiva destinada à explicação dos fatos sociais (positivismo) ${ }^{8}$.

Por isso, em decorrência desta lógica-mentalidade que exclui da ciência qualquer sobrecarga simbólica, preponderou, fundamentalmente, um divórcio entre saber estético e saber racional, também no período romântico, durante o século XIX. Nestas circunstâncias, esta ideologia - cientificista - acentuou a diferença entre o burguês racional e o poeta sonhador ${ }^{9}$. A partir disso, se pode dizer que, se iniciou, com isso, uma reviravolta caracterizada, essencialmente, pela coabitação de duas forças opostas, isto é, por um lado, o pragmatismo e o utilitarismo burguês pautados pela crença no progresso e na razão como possíveis soluções às mazelas humanas e, por outro, o devaneio romântico como reação contra a crença na razão, ressaltando, assim, a imaginação e os sentimentos.

Por isso, para a concepção positivista e progressista de Augusto Comte, o futuro da humanidade estaria na ciência bem como também e, em consequência deste pensamento, em um progresso humano e social advindo

descritiva”. Descrição não indica aqui um procedimento nos moldes, por exemplo, da morfologia botânica. A expressão tem novamente um sentido proibitivo: afastar toda determinação que não seja demonstrativa (HEIDEGGER, 2013, p. 74).

${ }^{8}$ Segundo Auguste Comte, um certo tipo de sociedade, caracterizado pelos dois adjetivos, teológico e militar, está em vias de desaparecer. O cimento da sociedade medieval era a fé transcendental, interpretada pela Igreja Católica. O modo de pensar teológico era contemporâneo da predominância da atividade militar cuja expressão era a atribuição das primeiras posições aos homens de guerra. Um outro tipo de sociedade, científica e industrial, está em vias de nascer. A sociedade que nasce é científica, no sentido em que a sociedade que morre era teológica: o modo de pensar dos tempos passados era o dos teólogos e sacerdotes. Os cientistas substituem os sacerdotes e teólogos como a categoria social que dá base intelectual e moral da ordem social. Estão em vias de receber dos sacerdotes, como herança, o poder espiritual que, segundo os primeiros Opúsculos de Comte, se encarnou necessariamente, em cada época, nos que oferecem o modelo do modo de pensar predominante, e fornecem as ideias correspondentes aos princípios da ordem social. Assim como os cientistas substituem os sacerdotes, os industriais, no sentido mais amplo- isto é, os empreendedores, diretores de fábricas, banqueiros-, estão assumindo o lugar dos militares. A partir do momento em que os homens pensam cientificamente, a atividade principal das coletividades deixa de ser a guerra de homens contra homens, para se transformar na luta dos homens contra a natureza ou na exploração racional dos recursos naturais (ARON, 1999, p. 66).

9 Temos, de algum modo, essa repartição de poderes, um poder concreto, real, que se irá ampliando ao longo do século através da revolução industrial, e um poder sobrerrogatório, o "um por cento" do poder estético que se irá separando cada vez mais. Daí o mal- 
de um estágio teológico (das imagens) inicial, passando a um estágio metafísico (dos conceitos), e que, por fim, evoluiria para o estágio positivo (científico), em que uma nova organização social, pautada pela ciência e pelo progresso, criaria e institucionalizaria um ideal racionalista de felicidade. Dessa maneira, na estrutura progressista de Comte, se compreendia o imaginário como um devaneio primitivo que cria, através da crença na ciência e no progresso, uma nova narrativa que nasce soterrando os mitos e, paradoxalmente, sobre estes escombros, é que se constrói o mito do progresso, "o mito progressista dos três estados, que se quis destruidor dos mitos, é ele próprio um mito" (DURAND, 1982, p. 20).

No entanto, o mito do progresso passa a ser questionado pelas narrativas românticas. Neste sentido, através deste questionamento, surgem obras como "Os miseráveis" de Victor Hugo, que denuncia a miséria e a injustiça social, mostrando, por um outro ângulo, uma outra face do progresso e da ciência. Além disso, no fim do século XIX, seguindo este questionamento-crítica, a doutrina marxista se apresentou como denúncia à exploração dos trabalhadores nas relações sociais de trabalho e, como ideal, esta doutrina acabou apontando para um caminho de superação do modo-lógica capitalística de produção como forma de reduzir ou, até mesmo, eliminar as desigualdades. Porém, o próprio socialismo, ideologia marxista, reabsorveu o mito progressista de estágios históricos de produção material e, com isso, manteve, não rompeu com a base racional e tecnicista capitaneada pela ciência moderna.

Posteriormente, em decorrência das mudanças na visão de mundo e na sensibilidade, no fim do século XIX, a estrutura mítica da sociedade se transformou e, por conta desta transformação, Nietzsche promoveu, no século XX, o declínio das grandes certezas. Dessa forma, houve, substancialmente, a relativização da verdade e, assim sendo, o critério da vida, presente na poesia, na imaginação, na mentira e na interpretação se sobrepôs, por assim dizer, ao critério da verdade.

Neste contexto, o fim das grandes certezas sedimentou, por sua vez, o firmamento sociocultural do século XIX e, às sombras do pessimismo moderno, projetou, no século XX, o nascimento de uma nova sensibilidade ou, melhor dizendo, de uma nova estrutura sociocultural, ou seja, de uma nova sociedade que passou a buscar, progressivamente, nos templos do consumo, do entretenimento, novas formas de dar sentido a sua existência.

A modernidade, alavancada como promessa de avanço em direção à liberdade, tomou um rumo oposto. A solidão, a insegurança e o medo são sentimentos que modelam, modernamente, a conduta-condição humana. Dito de outra maneira, o caos moderno, que caracteriza o contemporâneo estágio civilizacional, conduz a humanidade por meio de uma sensação de desorientação labiríntica. Fato é que, se Prometeu era a figura mítica que sustentava o pensamento do século XIX, em contrapartida, no século XX, a figura que sustenta o pensamento 
moderno é a do Minotauro ${ }^{10}$ que, além de tudo, se impõe como monstro devorador e como destruidor de mundo.

Este "monstro", qual seja, o Minotauro, é uma aberração que nasce da relação indevida entre homem e natureza. Assim, o surgimento desta criatura se dá, sobretudo, a partir do desejo de Pasífae que, pelo embuste, atrai o Touro e faz nascer, consequentemente, a Fera que, diante do desenrolar da trama, é ocultada no interior do labirinto. Neste caso, o labirinto surge para ocultar o fruto de uma relação perversa, mas também (é) e se apresenta (como) consequência da profanação do sagrado. Em decorrência disso, "o Rei Minos, ao não entregar o animal ao sacrifício, converte o benefício público em interesse próprio, desfaz o caráter de uma identidade comunitária e reforça o individualismo, suspende a unidade e o rito e inaugura a força e a beligerância" (CAMPBELL, p. 24, 1997).

O labirinto é um entrecruzamento de caminhos, múltiplas direções, onde se permite uma multiplicidade de escolhas e de erros. É uma estrutura mítica, uma metáfora da desorientação que se encontra subjacente ao modo de vida humano na contemporaneidade. Em outras palavras, o mito "é uma repetição de certas relações, lógicas, e linguísticas, entre ideias ou imagens expressas verbalmente" (DURAND, 1988, p. 18), isto é, é uma manifestação discursiva que arranja as imagens e os arquétipos produzidos pela imaginação humana, denominados mitemas.

Com isso, se pode dizer que, a mitodologia, no que se refere ao contexto contemporâneo, contribui para o desvelamento do regime mítico que subjaz esta determinada época, esta determinada sociedade assim como também aquilo que orienta ou (re)orientou a sua dinâmica e a sua sensibilidade. O mito diretivo de uma sociedade pode se manifestar pela redundância, ou seja, pelas imagens ou mitemas, que se organizam em constelações de imagens com traços comuns, e que remetem, ao mesmo tempo, à um mesmo significado, revelando, em decorrência disso, o substrato mítico dominante. Assim, "através das unidades constitutivas do discurso mítico (mitemas) apreende-se o esquema geral que evidencia o arsenal mitológico de uma época" (DURAND, 1982, p. 97).

\footnotetext{
${ }^{10} \mathrm{~A}$ figura do monstro-tirano é familiar às mitologias, tradições folclóricas, lendas e até pesadelos do mundo; e suas características, em todas as manifestações, são essencialmente as mesmas. Ele é o acumulador do benefício geral. É o monstro ávido pelos vorazes direitos do 'meu e para mim'. A ruína que atrai para si é descrita na mitologia e nos contos de fadas como generalizada, alcançando todo o seu domínio. Esse domínio pode não ir além de sua casa, de sua própria psique torturada ou das vidas que ele destrói com o toque de sua amizade ou assistência, mas também pode atingir toda a sua civilização. O ego inflado do tirano é uma maldição para ele mesmo e para o seu mundo - pouco importa quanto seus negócios pareçam prosperar. Auto- aterrorizado; dominado pelo medo; alerta contra tudo; para enfrentar e combater as agressões de seu ambiente - que são, primariamente, reflexos dos incontroláveis impulsos de aquisição que se encontram em seu próprio íntimo -, o gigante da independência auto conquistada é o mensageiro do desastre do mundo, muito embora, em sua mente, ele possa estar convencido de ser movido por intenções humanas. Onde quer que ponha a mão, há um grito (que, se não se eleva do exterior, vem - mais terrivelmente - de cada coração): um grito em favor do herói redentor, o portador da espada flamejante, cujos golpes, cujo toque e cuja existência libertarão a terra
} 


\section{OS NOVOS MITOS: A CIÊNCIA, A TECNOLOGIA E O MERCADO}

O mito é uma representação cultural dotada pelo imaginário de forças superiores, incompreensíveis e mágicas que, em um determinado espaço-tempo, foram reverenciadas pelo ser humano. Neste sentido, quando se fala de mito, se reporta, da mesma maneira, à esfera do sagrado. Por isso, em todas as culturas o mito se fez representar através de elementos sociais essenciais à coesão comunitária bem como também à criação de formas de repressão e de controle social. A mitanálise, por assim dizer, se apresenta, dessa forma, como uma análise sociológica dos mitos a partir do âmbito das instituições.

Com isso, se pode dizer, assim, que a Mitanálise possibilita um estudo metódico destas pluralidades semânticas que ocorrem no campo social, que variam no espaço e no tempo e que formam identidades simbólicas por meio de uma totalidade de significantes. Estes significantes, quais sejam: atitudes sociais, discursos, leis e relação com a natureza, flutuam na esfera social, se reagrupam e, por conta disso, instituem núcleos semânticos ou, melhor dizendo, discursos míticos que lançam, substancialmente, a sociedade em uma dimensão simbólica.

$\mathrm{Na}$ sociedade contemporânea, se instituiu uma multiplicidade de significantes, que constituem, em essência, as camadas míticas que (re)modelam a estrutura social, juntamente com as diversas narrativas que se imbricam, e que, entre estas, se encontra a metanarrativa mitológica da globalização e da lex mercatória que a acompanha.

A partir da teoria do imaginário de Gilbert Durand, se lança à uma dimensão simbólica para a compreensão da sociedade contemporânea, nesta perspectiva, por meio de algumas unidades semânticas que se realizam no contexto social. Para isso, se buscou instituir, através da narrativa mítica do labirinto, uma metáfora para conferir valor heurístico ao cenário global, hoje marcado por uma dimensão de incerteza e de desorientação.

Para se compreender a dimensão do mito bem como também desta estrutura social remodelada, se deve, em um primeiro momento, processar a ideia da estrutura mítica e, principalmente, em consequência disso, como ela surgiu, a partir da relação entre o sagrado e o profano, isto é, de uma dimensão em que se complementam ou se separam. Para este intento e de acordo com Nietzsche se remontou, por sua vez, à tragédia grega para possibilitar uma reconciliação entre o sagrado (Apolíno) e o profano (Dionísio), pois, para ele, a tragicidade remetia à crueza da vida por meio da arte. Todavia, as expressões dionisíacas, dor, sofrimento, sexo, traição estão ali presentes, mas são experiências ilusórias que recebem o contorno da arte mimética, e que, por isso, se configuraram através de um espetáculo de bela aparência, concebendo, neste contexto, o controle racional apolíneo.

Esta dimensão apolínea (racional) e dionisíaca (irracional), resgatada por Nietzsche, orientou toda a lógica que instaurou as sociedades industriais surgidas na Europa, e que se expandiram, em consequência disso,

(CAMPBELL, 1997, p. 25). 
por meio do colonialismo. Porém, diferentemente da tragédia grega, na qual as duas experiências se harmonizaram, aqui há uma cisão que impera a supremacia Apolínea, e que, por meio desta cisão, faz surgir um outro mito, o do progresso, sustentado pelo cientificismo que tolhe qualquer experiência "irracional".

Estas novas abordagens epistemológicas e culturais forneceram outros contornos, ou seja, os contornos para uma racionalidade instrumental que, por sua vez, deriva do racionalismo matemático dedutivo de Descartes e do empirismo baconiniano, cujas bases se sustentam no positivismo científico. Dessa forma, o conhecimento passou a operar unicamente através da experiência direta, descartando o imaginário simbólico que ficou, progressiva e contemporaneamente, restrito a setores de manifestação artística. Nestas circunstâncias, com a dessacralização operada pela modernidade e efetuada pela racionalidade instrumental subsumida à racionalização e à matematização da realidade, se erigiu, em decorrência disso, toda uma epistemologia de dominação do ser humano e da natureza.

Esta nova dimensão, à semelhança do Médico e do Monstro, protagonizou avanços formidáveis da técnica assim como também criou uma tecnosfera dotada de uma nova semiosfera, cujos aspectos místicos sensíveis, por meio do desencantamento das formas religiosas, espirituais e artísticas, subsumidas ao artifício técnico racional, foram reduzidos apenas ao espectro linear e evolutivo da ciência.

Por outras palavras, os demais setores do imaginário passam a ser compreendidos, por conta disso, como parte da crendice, da heresia, do esoterismo e dos saberes obscuros e inferiores remanescentes do Estado Teológico místico e anacrônico que, outrora, representou, por sua vez, uma oposição ao mundo epistemológico da ciência, contemporaneamente entendida como uma estrutura narrativa mítica fundada no ideal de progresso prometeico, o qual retiraria a humanidade de sua infância arcaica e primitiva.

Por isso, o resgate de uma esfera mítica se constitui, na atualidade, em um dos esforços mais formidáveis, imprescindíveis e como condição de possibilidade à criação de uma sagrada laicidade capaz de desafiar todo o contexto de destruição e de colapso ambiental iminente. Tudo isso, se apresenta, assim, como um desafio ético e estético, pois, a fruição das imagens, através de um viés simbólico e (des)coisificador, se faz necessária nestes processos de interpretação e de construção práxica da realidade.

Ademais, se faz prudente diagnosticar, sem maniqueísmos irredutíveis, as chagas - carências e riscos - do atual modelo de desenvolvimento que, ao lado de uma pretensa prosperidade consumista sem precedentes, aniquila o planeta com base em uma acumulação desenfreada de matéria e de energia.

Dessa forma, se pode dizer que, tudo isso, deriva da mitologia de um mercado global, sagrado para o economicismo, e que, por conta desta (des)sacralização, impede qualquer regulação ou controle sobre a sua capacidade de destruição. Assim, o período contemporâneo, por sua vez, se consubstancia em uma nova era geológica, marcada pela ação do homem na Terra, o Antropoceno, o qual, sobretudo, iguala o poder de destruição 
do ser humano ao provável impacto dos asteroides, isto é, dos eventos cataclísmicos que dizimaram, em um determinado momento histórico, grande parte da biodiversidade.

Todavia e em decorrência disso, surge a necessidade de uma ética do guardião e da responsabilidade, cuja premissa substancial, enquanto resta tempo, se constituirá, por assim dizer, em uma das formas de buscar a saída da contemporânea seara mítica-metafórica do labirinto. É, neste sentido, que o Minotauro poderá ser o novo mito que substituirá a crença mítica na ciência prometeica.

Por conta disso, ou seja, por conta deste cenário mítico-econômico, ao que parece, não há afirmação mítica viável sem a dimensão de uma ética da alteridade baseada em uma nova reciprocidade entre seres humanos bem como também entre estes, enquanto civilização múltipla, e a natureza como base para o sustento e para o surgimento da vida.

A erosão da crença no caminho único do progresso e na redenção da humanidade pela técnica estabeleceu, assim, novos objetivos para um novo herói, o qual deve encarnar o desafio de lutar contra o Minotauro, a exemplo de Teseu, em uma era de absoluta descrença nos deuses, que foram mortos pela ciência, essa nova Pitonisa sacerdotal que decifra os augúrios do futuro.

Dessa forma, assim como Teseu, que fora auxiliado por Dédalo e Ariadne, o novo discurso ecológico poderá proporcionar novas práxis capazes de inaugurar um novo sagrado ecológico, produzindo uma nova história-sacralização, em que o herói, auxiliado por um fio capaz de dirigi-lo para uma outra ou para uma nova saída, é levado por uma nova crença capaz de salvar a humanidade, em um momento paradigmático de extermínio das utopias e de aceitação resignada do colapso iminente.

O pessimismo melancólico das utopias mortas e o ufanismo de um progresso já desmascarado, devem ceder espaço para uma nova síntese simbólica e dialógica, intercultural e pluralmente emancipatória. Estas novas possibilidades que, por sua vez, poderiam construir um fio condutor destinado à busca de um novo cosmopolitismo pautado no ecológico, deverão se consubstanciar, substancialmente, em uma sociedade civil planetária guiada pela ética ambiental como condição de possiblidade à fuga do Niilismo que, ao fim e ao cabo, poderá, se a apropriação-destruição da natureza perdurar, produzir um enforcamento através do fio simbólico e antropológico (catástrofes) de Ariadne.

Para isso, se torna necessário encontrar os fios de Ariadne na sociedade civil e em um novo modelo de constitucionalismo global capaz de atacar aspectos significativos da Crise Antropológica bem como também de um mercado afirmador de poderes "mágicos" e "sagrados" que não podem ser profanados. O egoísmo profano do individualismo jurídico deverá ceder lugar à solidariedade mítica do herói, que se projetará, por sua vez, além do individualismo cego de uma ciência convertida para o mercado.

Assim, a grandeza do herói se caracterizará pela ultrapassagem da obscenidade de uma vida sem sentido 
que, sobretudo, se sustenta, atualmente, apenas pelo status do consumo. A partir desta marcha, ou seja, desta viragem, é que se constituirá um caminho alternativo traçado pelo herói, cuja busca, por um destino de glória comum, em simbiose com a terra, poderá, à duras penas, construir um novo cenário de mundo-morada, base terrena, sagrada e profana que aglutina esta civilização.

O discurso único, fruto da ciência, da tecnologia e do mercado, deve ser superado pelo processo de adensamento de uma abordagem intercultural, capaz de promover a via dialógica entre os diferentes contextos de significação da humanidade.

Neste contexto, como saída-salvação à humanidade e, fundamentalmente, à natureza, se suscita, a partir desta conjuntura, a construção de um contrato natural cosmopolita capaz de controlar o risco e a incerteza, como o herói controlou o Minotauro e a sua sede devoradora de seres humanos.

Em consequência disso, se pode dizer que, este contrato, agora natural, terá como premissa fundamental evitar a "canibalização" das gerações humanas futuras e da própria natureza, impedindo, dessa maneira, a transformação do planeta em fazendas, áreas de mineração, de poluição insana devido à falta de um senso ético e de responsabilidade que remonte à uma dimensão mítica.

Esta nova ética ecológica, pautada na crença de um valor intrínseco da vida, enquanto realidade sagrada e transcendente, poderá ou intentará desconstruir os domínios do imediato, do egocentrismo e do individualismo humano. A união do ser humano em torno de um propósito comum poderia, como uma nova resposta-proposta, contrapor a dimensão técnica e, em seu lugar, promover-planetarizar uma via heroica, uma nova ética do sagrado laico como fantasia, lenda, sugerindo, assim, uma dimensão simbólica em construção no plano onírico.

Por conta disso, através desta nova sensibilidade ética, poderá-deverá emergir um posicionamento valorativo que, ao fim e ao cabo, constituirá um novo direito. Direito este, consubstanciado a partir de uma viragem ecológica e biocêntrica estabelecida, essencialmente, por meio de uma via dialógica profunda. Esta nova pedagogia global, advinda de uma antropologia capaz de internalizar este novo direito, se apresenta ou, deverá se apresentar, contemporaneamente, como condição de possibilidade para uma nova inter-relação do homem com a natureza, isto é, da humanidade com a sua morada (des)sacralizada.

Portanto, parece, dessa forma, que o modo pelo qual se transforma a natureza, será contraposto, por assim dizer, a partir de uma nova concordância prática, exprimida pela consensualidade jurídica, cuja operacionalidade, fundamentalmente em consonância com a democracia, deverá produzir um diálogo que, nesta lógica, possibilite a percepção da complexidade e da multiplicidade que caracterizam o hodierno cenário.

Será dessa forma e neste sentido, que se poderá desenhar um novo constitucionalismo, pelo qual deverá ser inaugurada uma práxis jurídica voltada à efetivação de uma saída para o ser humano, ou seja, de um novo projeto jurídico capaz de transformar o projeto antropológico e, com isso, do jurídico e do antropológico, fazer 
surgir uma promoção destinada à manutenção da biodiversidade e das condições de salubridade planetária, delineando, assim, uma (re)construção da geografia do mundo, que tentará construir, por conta desta conjunção, qual seja, jurídica e antropológica, uma possível condução da humanidade a uma saída sustentável do labirinto.

Por isso, o cosmopolitismo jurídico, que se anuncia como essencial à geração de um novo sistema de crenças, por sua vez, deverá conduzir, também, a uma mentalidade solidária, sem a qual o caminho da salvação individual, do império do desejo, do efêmero e do vazio, gerado pelo consumismo, continuará triunfando.

Neste contexto, via constitucionalismo, haverá um reencantamento da geografia, da política e da cidadania, de modo que, como reflexo disso tudo, seja viabilizada a promoção do diálogo a partir da dimensão do existir, e que, este diálogo, ao transcender as molduras da racionalidade instrumental, no sentido de uma sensibilização da práxis jurídica assim como também das demandas socioambientais, possibilite uma saída (do) e uma ruptura (com) o labirinto.

\section{DO CONSTITUCIONALISMO E DE SUAS RESPONSABILIDADES COMO UM NOVO FIO DE ARIADNE}

Nas narrativas mitológicas, a jornada se apresentou, inicialmente, por meio de uma adversidade que, em detrimento da narrativa, necessitou, substancialmente, de uma ação heroica para dirimir o conflito. Entretanto, em contrapartida, inserido em um eterno ciclo como representação da temporalidade atual, o herói poderá não ouvir o chamado, pois, "aprisionado pelo tédio, pelo trabalho duro, pela cultura, o sujeito perde o poder de ação afirmativa dotada de significado e se transforma em vítima a ser salva" (CAMPBELL, 1997, p. 66).

O iminente colapso ambiental, da pior maneira possível, poderá possibilitar um resgate da crença dialógica e, assim, da mesma forma, poderá promover a esperança a partir de um projeto jurídico constitucional cosmopolita. Dessa maneira, como característica disso tudo, se pode dizer que, a prevalência das necessidades do grupo e da comunidade, em detrimento das necessidades do indivíduo, se constituíra, indubitavelmente, como um novo senso comum jurídico, cuja primordial função estará adstrita à retomada do sagrado como limite ao profano. De fato, por conta deste resgate, a coletividade, consubstanciada por uma nova sensibilidade, será convocada a aderir a esta jornada heroica, qual seja, salvar a Terra.

Em consequência disso, o colapso do modelo salvífico do mundo, amparado em um arquétipo de idealização angeológico de salvação, opera através de dispositivo ${ }^{11}$, ou seja, por meio de formas de gestão da vida. Por isso, o homem, nesta lógica é, cronologicamente, capturado por uma rede de dispositivos que não é exclusiva da modernidade, mas correlata, substancialmente, ao processo de hominização.

\footnotetext{
${ }^{11}$ [...] qualquer coisa que tenha de algum modo a capacidade de capturar, orientar, determinar, interceptar, orientar, modelar, controlar e assegurar os gestos, as condutas, as opiniões e os discursos dos seres viventes (AGAMBEN, 2014, p. 12)
} 
Para ecologizar este processo de hominização, o constitucionalismo deverá ser dirigido por uma mística principiológica bem como também pelo senso coletivo ecológico. Caso contrário, se transformará em prática kafkiana, na qual o procedimentalismo puro se apresentará como forma autopoiética, isto é, como acoplamento estrutural. Assim, construir uma nova dimensão - constitucional e ecológica - como fio condutor, poderá possibilitar uma abertura destinada a novas epistemologias sócio-jurídicas e culturais, de modo que, estas epistemologias, (res)sacralizem o ciclo biológico da natureza e, principalmente, a inter-relação homem e meio ambiente.

Como no mito de Sísifo, ao invés da pedra, o homem acorda para acumular novos bens e contrair novas dívidas. Esta prática, que na contemporaneidade atribuiu e atribui progressivamente sentido à existência humana, por meio deste projeto civilizacional, é a representação da excreção do lixo existencial gerado pela obsolescência programada da matéria e do espírito que, por sua vez, se encontra demarcada, indubitavelmente e historicamente, a partir deste singular habitar-morar - humano - na terra.

Estas práticas nocivas e parasitárias, capitaneadas por este projeto moderno de humanidade produzem, por assim dizer, uma entropia em escala planetária. Desse modo, estas práticas inviabilizam a recomposição das condições de estabilidade planetária a curto, a médio e a longo prazo. Parece, assim, que a entropia humana se equipara às catástrofes ambientais geradas no passado.

Em consequência disso, os processos antrópicos e entrópicos de extração, produção e consumo geram, constantemente e desde a Revolução Industrial, emissões industriais de dióxido de carbono. Este modo de desenvolvimento, contemporaneamente ampliado e agravado, intensifica o aquecimento global. Dessa forma, existe um consenso dialógico e científico acerca das causas dos problemas experimentados por conta da destruição ambiental assim como também, em um primeiro momento, em decorrência da coisificação da natureza.

Há, também, um outro consenso, qual seja: que a problemática diagnosticada impede, substancialmente e contemporaneamente, a constituição de um fio de Ariadne que possua, como desiderato, o afastamento do antropocentrismo prometeico. Assim, a fuga dos caminhos labirínticos impostos pela catastrófica realidade, no que se refere a uma viragem ecológica, evitaria, sobretudo, a transformação da Terra em ruína.

Neste sentido, a partir do modo pelo qual se habita e mora na Terra, ou seja, da cultura antropológica empregada nesta habitação, metaforicamente similar ao híbrido representado pelo Minotauro e pelo pecado em face do Rei Minos por ele realizado e, com isso, punido por Zeus, é que hoje, diferentemente das circunstâncias mitológicas, a civilização construída na modernidade, se encontra à deriva e, por assim dizer, entregue à ira de gaia.

Todavia, a remitologização deverá ser operada por meio da desmitificação da atual base mitológica e científica do direito que, assim sendo, se encontra, essencialmente, sacralizada pelo profano tecnicizado. Este novo 
direito, não se conceberá como fora concebido no passado o fio de Ariadne, pois, deverá ser concebido como ponto de libertação ou, caso contrário, o presente fio, perdido no vazio do labirinto tecnocientífico, mercadológico e antropológico, poderá, por sua vez, enforcar o ser humano.

A nova interpretação do fio de Ariadne, aqui apresentada é, a partir de um viés axiológico-ecológico, condição de possibilidade para um politeísmo de valores, cuja finalidade se encontra adstrita à refundação do homem, do constitucionalismo bem como também do Estado.

Esta nova estética jurídica, além de partir do Antropológico, do Jurídico e do Político, partirá, também, da crítica à narrativa neo-hegeliana do fim da história que, por assim dizer, fora edificada pelas crenças oníricas de uma globalização capaz de construir a felicidade através da mitologia do consumo, juntamente com os seus templos dionisíacos que representam, fundamentalmente, um labirinto sem saída.

Dito de outra forma, uma nova mitologia jurídica deverá nascer como sopro do caos contemporâneo, pois, este cenário-imagem produzido, a através desta situação catastrófica, se apresenta como fruto da descrença no caldeirão profano $^{12}$ do mercado e como representação do progresso que, em substância, constitui a modernidade e, produz, em consequência disso, mitologias totalitárias que vitimam os vencidos - todos os seres vivos - e destroem entropicamente a natureza.

\section{CONSIDERAÇÕES FINAIS}

Portanto, ainda que se esteja longe de qualquer conclusão relativa à saída deste labirinto global assim como também de uma flexibilização do dogmatismo da ciência, da tecnologia e do mercado, se buscou, no presente texto e, a partir da análise do Mito do Labirinto, compreender as causas da Crise Ecológica e, em consequência disso, a ausência de alternativas, no que se refere à contemporaneidade, ocasionada por esta problemática.

Perante a situação traçada, entre dificuldades e possibilidades à uma transição para um futuro desconhecido e não planejado, o constitucionalismo, como condição prévia de determinação, em escala global, poderá traçar ou não o que está por vir, ou seja, a poluição como fenômeno caracterizador da humanidade. Assim, em meio à essa circunstância, poluição como cultura civilizacional, o que se produziu, até o hodierno momento, foram questionamentos sobre a irregularidade do homem como arquiteto de um futuro comum sustentável.

Ademais, para esse futuro comum, isto é, para a saída deste labirinto, se faz necessário rediscutir, em um contexto global, a substituição da soberania nacional pela responsabilidade, via constitucionalismo, como garantia fundamental para um novo projeto antropológico de sociedade. Desta feita, neste sentido, deverá se espraiar, 
também, a utopia da promessa social, juntamente com a salvaguarda da questão ambiental, como principal garante - em uma concepção planetária de sociedade e de constitucionalismo - do direito ao futuro.

A pauta da discussão, aqui evidenciada, remete, indeclinavelmente, para aquilo que atualmente ainda castiga o homem e destrói o meio ambiente: o próprio homem e a sua incapacidade de reinventar a natureza e, ao mesmo tempo, de preservá-la, promovendo, assim, a igualdade social em um contexto (entre passado e presente) de iminente catástrofe. A sorte está lançada e, com isso, a possibilidade ou não de continuidade da vida. Para isso, ainda o constitucionalismo!

\title{
ENTER, STAY OR LEAVE THE LABYRINTH? CONSTITUTIONALISM AND - SOCIAL, ENVIRONMENTAL AND GLOBAL - SIMULTANEOUSNESS OF EVENTS
}

\begin{abstract}
This paper aims to discuss about the Myth - metaphor - the Labyrinth as well as of constitutionalism as civilizational responsibility and at the same time as rescue - Contemporary - the mythological Ariadne wire. Also, be discussed in this text about science, technology and the market as representations of the modern anthropological project that substantially instituted and establishing - gradually - a labyrinthine scenario of environmental destruction.
\end{abstract}

Keywords: Myth; Maze; Ecological Crisis; Constitutionalism; Globalization.

\section{REFERENCIAS BIBLIOGRÁFICAS}

AGAMBEN, Giorgio. O amigo \& o que é um dispositivo. Chapecó, SC: Argos, 2014.

UFMG, 2011.

O sacramento da linguagem: arqueologia do juramento (Homo sacer II, 3). Belo Horizonte: Editora

Profanações. São Paulo: Boitempo, 2007.

ARON, Raymond. As etapas do pensamento sociológico. São Paulo: Martins Fontes, 1999.

DELMAS-MARTY, Mireille. Por um direito comum. São Paulo: Martins Fontes, 2004.

BOLZAN DE MORAIS, Jose Luis. As crises do Estado e da Constituição e a transformação espaço-temporal dos direitos humanos. Porto Alegre: Livraria do Advogado Editora, 2011.

CAMPBELL, Joseph. O Herói de mil faces. São Paulo: Editora Pensamento LTDA, 1997.

DURAND, Gilbert. Mito, símbolo e mitodologia. Lisboa: Presença, 1982.

\footnotetext{
12 O improfanável da pornografia - qualquer improfanável - baseia-se no aprisionamento e na distração de uma intenção autenticamente profanatória. Por isso é importante toda vez arrancar dos dispositivos - de todo dispositivo - a possibilidade de uso que os mesmos capturaram. A profanação do improfanável é a tarefa da política da geração que vem (AGAMBEN, 2007, p. 79).
} 
_A imaginação simbólica. São Paulo: Cultrix, 1988.

HEIDEGGER, Martin. Ser e Tempo. Petrópolis, RJ: Vozes; Bragança Paulista, SP: Editora Universitária São Francisco, 2013.

Caminhos de Floresta. Lisboa: Fundação Calouste Gulbenkian, 2014.

Trabalho enviado em 24 de abril de 2016.

Aceito em 25 de agosto de 2016. 